\title{
Survival analysis of patients with biochemical relapse after radical prostatectomy treated with androgen deprivation: Castration-resistance influential factors
}

\author{
Rubén Algarra, MD; Mateo Hevia, MD; Antonio Tienza, MD; Imanol Merino, MD; José María Velis, MD; \\ Javier Zudaire, MD; José Enrique Robles, MD; Ignacio Pascual, MD
}

Department of Urology, University of Navarra Clinic, Navarra, Spain

Cite as: Can Urol Assoc J 2014;8(5-6):e333-41. http://dx.doi.org/10.5489/cuaj.1665 Published online May 21, 2014.

\section{Abstract}

Introduction: We evaluate the prognosis of patients with biochemical recurrence (BCR) treated with androgen deprivation therapy (ADT) and to determine the influential factors to castration resistance (CR) and death.

Methods: From a series of 1310 patients with T1-T2 prostate cancer treated with radical prostatectomy between 1989 and 2012, 371 had BCR. Patients with lymph node involvement were excluded. We analyzed only the 159 treated with salvage ADT. At the end of the study, 77 (48\%) had developed CR.

Results: The median follow-up to CR was 9.2 years. The CR-resistant free survival (RFS) was $76 \pm 3 \%, 62 \pm 3 \%$ and $43 \pm 9 \%$ in 5,10 and 15 years, respectively. The RFS median time was 14 years. In the multivariate study, the prostate-specific antigen (PSA) doubling time (PSA-DT) was $<6$ months $(p=0.01)$ (hazard ratio $[\mathrm{HR}] 3$; 95\% confidence interval $[\mathrm{Cl}] 1.4-6.8, p=0.007)$; seminal vesicle involvement (HR 3.1; 95\% Cl 1.5-6.2, $p=0.01)$ and PSA velocity in $\mathrm{ng} / \mathrm{mL} /$ year $(\mathrm{HR} 1.3 ; 95 \% \mathrm{Cl} 1.1-1.5, p=0.002)$ with better cut-off points of $0.84 \mathrm{ng} / \mathrm{mL} /$ year $(p=0.04)$ (HR 4 ; $95 \% \mathrm{Cl} 1.7$ $9.4, p=0.001$ ) were influential variables. Specific survival (SS) at 5,10 and 15 years since surgery was $96 \pm 1,85 \pm 2$ and $76 \pm 4$, respectively. The time of CR to death was $30 \pm 6 \%$ at 5 years, with the median at 3.2 years. In the multivariate only Ki 67 (HR 1.04; 95\% Cl 1.005-1.08, $p=0.02$ ) had an independent influence. Conclusions: In BCR patients treated with ADT, the median to $C R$ was 14 years. PSA-DT $<6$ months, PSA velocity ( $\mathrm{ng} / \mathrm{mL} /$ year) and seminal vesicle involvement were influential variables. From the $\mathrm{CR}$, the median time to death was 3.2 years. Ki-67 marker was an independent influence.

\section{Introduction}

In patients treated with radical prostatectomy, $15 \%$ to $40 \%$ of them have biochemical recurrence (BCR). ${ }^{1-6}$ Of these, at least
$40 \%$ to $60 \%$ are treated with androgen deprivation therapy (ADT). ADT is a palliative treatment already called castration, and in some cases patients develop castration resistance (CR). ${ }^{7}$ New therapeutic options have been developed, however, once CR has developed death is unavoidable. ${ }^{8,9}$

It is important to know the clinic-pathological predictive factors of time to $C R$ and time to death. The therapeutic attitude in prostatectomized patients with BCR depends on these factors. There are several studies about the time to death or time until evidence of metastasis in patients with BCR that were treated with deferred ADT. 1,10,11 There are also studies about the influence of the BCR time on overall survival, ${ }^{12}$ about the factors of influence on disease-specific survival (SS), ${ }^{13,14}$ and about its comparison with the SS in patients without recurrence. ${ }^{2}$

We studied the clinic-pathological factors of influence in time to CR and time to death in 159 patients (from a series of 1310 patients treated with radical prostatectomy) with subsequent BCR treated with immediate complete ADT.

\section{Methods}

We retrospectively analyzed a series of 1310 patients with prostate cancer qualified as T1-T2 according to the TNM criteria and treated with radical prostatectomy between January 1989 and December 2012.

From the whole series, 371 showed BCR. Subsequently, patients with lymph node involvement were excluded. In total, 313 (23.9\%) were part of the study. All patients were treated with radical therapy. Of the 313, 91 (29.1\%) received radical radiotherapy, $63(20.1 \%)$ radical radiotherapy and concomitant ADT and $159(50.8 \%)$ received ADT. We only analyzed the 159 treated with ADT in rescue scheme, 77 of whom developed CR.

The selection of a rescue-specific treatment depended on the personal decision of each physician.

CR occurs when patients undergo ADT despite their pro- 
gressive elevation of serum prostate-specific antigen (PSA) levels. As per the 2013 Canadian Urological Association guidelines criteria, ${ }^{15}$ castration-resistant prostate cancer (CRPC) is defined by disease progression despite ADT and may present as either a continuous rise in serum PSA levels, the progression of pre-existing disease, and/or the appearance of new metastases.

Before surgery, a detailed medical history with a physical examination (including rectal examination), PSA and prostate biopsy were performed in every patient. The study was completed with a computed tomography (CT) scan until July 2000. After that point, a magnetic resonance image (MRI) was taken with no special criteria due to the fact that the initial target was to manage MRI diagnostic effectiveness ( $\mathrm{n}=729$ patients).

Up until 2000, a bone gammagraphy was done in all patients. Since that time, it was only used in patients with a PSA higher than $20 \mathrm{ng} / \mathrm{mL}$ or Gleason score $>6$. In every case, a modified retropubic radical prostatectomy, according to the technique described by Walsh in $1982,{ }^{16}$ was performed and was completed systematically with bilateral ilio-obturator node dissection until 2007. As of 2007, the modified retropubic radical prostatectomy was only done in patients with a PSA $>15 \mathrm{ng} / \mathrm{mL}$, clinical Gleason score $\geq 7$, or clinical stage T2b. The laparoscopic approach was performed at our center for the first time in 2005.

Two urological sub-specialized pathologists examined the retrieved specimens according to the technique described by True. ${ }^{17}$ We also studied the Ki-67 expression.

In $2000,{ }^{18}$ we found that $\mathrm{Ki}-67$ was associated with a worse prognosis and worse cancer stage in operated patients. We now want to assess whether this trend is confirmed in patients with CR. Since 2000, the determination of Ki-67 was made in 99 patients (from the 159 with CR). All immunohistochemical analyses were performed in sections of 4 microns, fixed in formalin and obtained from the primary tumour, which was included in paraffin. Immunohistochemistry was performed with an automatic inmunohistainer (Techmate 500; Dako, Copenhagen, Denmark) with the Envision and System Dako, in which the secondary antibody is coupled to a dextran polymer linked to peroxidase molecules. Endogenous peroxidase activity was neutralized with 5\% hydrogen peroxide, in methanol solution for 30 minutes at room temperature. Antigen retrieval was performed with a microwave treatment for 20 minutes at 800 watts. Rabbit serum was phase-locked. The primary antibody was applied for 120 minutes at room temperature; sections were then washed with a washing buffer. The next step was to add the reagents with the Envision and System and incubate them for 30 minutes. The plates were washed with a wash buffer and treated with a $0.05 \%$ diaminobencina hydrochloride solution and $0.1 \%$ hydrogen peroxide $0.05 \mathrm{~mL} / \mathrm{L}$ of TRIS buffer saline at $\mathrm{pH} 7.4$ at room temperature, for 5 minutes. After the distilled water wash for 3 minutes, preparations were stained with hematoxylin Harris modified solution, dehydrated and mounted. Lamb normal serum was used for the negative control instead of the primary antibody (MIB1, Zymed). The result was expressed in a percentage of stained cells.

Analytics tracking was performed using PSA determinations at 3, 6 and 12 months after surgery. Then, every 6 months for a total of 3 years, and subsequently, every year. Following the recommendations of the Prostate Cancer Clinical Trials Working Group (PCWG2), BCR was defined as the determination of PSA $\geq 0.4 \mathrm{ng} / \mathrm{mL}^{19}$ (Hybritech, Tandem) obtained at least 30 days after surgery and later confirmed with an equal or greater value.

For the PSA doubling time calculation (PSA-DT in months), a minimum of 2 PSA $(\mathrm{ng} / \mathrm{mL})$ determinations were obtained after BCR and it was calculated by the following formula: Ln $2 \times$ DT/Log PSA2 - Log PSA1. With these values the growth of PSA velocity is also computed in $\mathrm{ng} / \mathrm{mL} /$ year (Velocity = PSA1 + 21/DT).

Our goals for this study were twofold: (1) to assess the time from surgery to $\mathrm{CR}$ and the clinic-pathological factors of influence; and (2) to study the time from CR to death and the factors of influence.

Chi-square or Fisher exact $\mathrm{F}$ testing and contingency tables were used to compare qualitative variables. The normality distribution of quantitative continuous variables was determined using Kolmogorov-Smirnov and Shapiro-Wilk tests. Quantitative variables (age [years], PSA [ng/mL]) and Ki-67) did not follow a normal distribution and non-parametric tests were used for comparison (Mann Whitney $U$ test).

The receiver operating characteristic (ROC) were used to pursue ideal cut points in continuous variables. To assess the actuarial survival, we used the Kaplan-Meier method; to compare survival curves, we used the log-Rank test.

A Cox regression analysis was used to determine survival influential variables (univariate and multivariate study). Statistical significance and hazard ratio $p$ values with their respective confidence intervals were calculated and estimated respectively by the Bootstrapping technique with 1000 replications.

All statistical analyses were performed using SPSS expanded version 22.0 (SPSS Inc., Chicago, IL). All data were presented as mean \pm standard deviation or number $(\%)$. A $p$ value of less than 0.05 was required to determine the statistical significance.

\section{Results}

The mean and median time to BCR of patients treated with $A D$ was 27 and 14 months, respectively. The median follow-up of the entire group (159 patients) was 9.2 years. For the 82 patients in BCR without CR, it was 9.2 years; for the 77 patients with CR, it was 7.7 years. We tallied the 
clinico-pathological characteristics of our study patients (Table 1).

\section{Time to CR study}

At the end of the study, 77 patients (48\%) had developed CR. CR resistance-free survival (RFS) is $76 \pm 3 \%, 62 \pm 3 \%$ and $43 \pm 9 \%$ at 5, 10 and 15 years, respectively (patients at risk 93, 39, 5). Median RFS was 14 years (95\% confidence interval $[\mathrm{Cl}] 11-17$ years) (Fig. 1).

In the univariate study (Cox model), the RFS influential factors were seminal vesicle involvement, pathological Gleason 8-10, having been operated among the first 500 patients in the series (1989-1999), PSA doubling time

\begin{tabular}{|c|c|c|c|c|}
\hline BCR patients & No. & No CR & CR & $p$ value $^{\dagger}$ \\
\hline $\mathrm{N}$ & $159(100 \%)$ & $82(51.6 \%)$ & 77 (48.4\%) & \\
\hline \multicolumn{5}{|l|}{ Clinical variables } \\
\hline \multicolumn{5}{|l|}{ Age (years) } \\
\hline $64.4 \pm 6.1$ & & $64.6 \pm 5.8$ & $63.4 \pm 6.7$ & $\leq 0.1$ \\
\hline \multicolumn{5}{|l|}{ Initial PSA (ng/mL) } \\
\hline $18.8 \pm 15.5$ & & $18.2 \pm 15.3$ & $20.2 \pm 16.7$ & $\leq 0.3$ \\
\hline \multicolumn{5}{|l|}{$B M I\left(k g / m^{2}\right)$} \\
\hline $28.1 \pm 4$ & & $27.8 \pm 3.7$ & $28.2 \pm 4.6$ & $\leq 0.8$ \\
\hline \multicolumn{5}{|l|}{ Abnormal rectal examination } \\
\hline $90(56.6)$ & & $40(48.7)$ & $50(65)$ & $\leq 0.09$ \\
\hline \multicolumn{5}{|l|}{ Biopsy diagnostic (T1c) } \\
\hline $60(37.7)$ & & $32(39)$ & $28(36.3)$ & $\leq 0.4$ \\
\hline \multicolumn{5}{|l|}{ Gleason score } \\
\hline $2-6$ & $88(55.3)$ & $39(47.6)$ & $49(63.6)$ & \\
\hline 7 & $35(22)$ & $25(30.5)$ & $10(13)$ & \\
\hline $8-10$ & $36(22.6)$ & $18(21.9)$ & $18(23.4)$ & $\leq 0.09$ \\
\hline \multicolumn{5}{|l|}{ Clinical stage } \\
\hline T1a-c & $56(35.2)$ & $34(41.5)$ & $22(28.6)$ & \\
\hline$T 2 a-b$ & $62(38.9)$ & $35(42.7)$ & $27(35)$ & \\
\hline $\mathrm{T} 2 \mathrm{c}$ & $41(25.8)$ & $13(15.8)$ & $28(36.3)$ & 0.000 \\
\hline High-risk D'Amico & $93(58.5)$ & 45 (54.8) & $48(62.3)$ & $\leq 0.2$ \\
\hline \multicolumn{5}{|l|}{ Pathological variables } \\
\hline \multicolumn{5}{|l|}{ Pathological stage } \\
\hline pT2 & $45(28.3)$ & $29(35.3)$ & $16(20.7)$ & \\
\hline pT3 & $55(34.6)$ & $33(40.2)$ & $22(28.6)$ & \\
\hline pT3b & $59(37.1)$ & $20(24.4)$ & $39(50.6)$ & $\leq 0.003$ \\
\hline Positive surgical margins & $97(61)$ & $52(63.4)$ & $45(58.4)$ & $\leq 0.8$ \\
\hline \multicolumn{5}{|l|}{ Pathological Gleason } \\
\hline $2-6$ & $54(33.9)$ & $22(26.8)$ & $32(41.5)$ & \\
\hline 7 & $49(30.8)$ & $34(41.4)$ & $15(19.4)$ & \\
\hline $8-10$ & $56(35.2)$ & $26(31.7)$ & $30(39)$ & $\leq 0.04$ \\
\hline Ki-67 marker & $8.3 \pm 10.5$ & $8.5 \pm 11.7$ & $7.8 \pm 7.6$ & $\leq 0.7$ \\
\hline \multicolumn{5}{|l|}{ State } \\
\hline Live in progression & $101(63.5)$ & 77 (93.9) & $24(31.2)$ & \\
\hline Dead of prostate cancer & $47(29.5)$ & $0(0)$ & $47(61)$ & \\
\hline Died of other causes & $11(7)$ & $5(6.1)$ & $6(7.8)$ & 0.000 \\
\hline \multicolumn{5}{|l|}{ Follow-up (years) } \\
\hline Mean & $9.4 \pm 4.2$ & $9.4 \pm 4$ & $8.6 \pm 4.2$ & \\
\hline Median & $9.2(0.2-19.5)$ & $9.2(0.9-19.5)$ & $7.7(0.2-17.5)$ & \\
\hline
\end{tabular}

Data presented as mean \pm DS or number $(\%)$.

${ }^{*} \mathrm{n}=159$ prostatectomized with AD by BP; ${ }^{\dagger} p<0.05$; PSA: prostate-specific antigen; BMI: body mass index; ADT: androgen deprivation therapy; BCR: biochemical recurrence; CR: castration resistant. 
Algarra et al.

(PSA-DT) $<6$ months, PSA velocity in $\mathrm{ng} / \mathrm{mL} /$ year, and PSA velocity with the best cut-off point as $0.84 \mathrm{ng} / \mathrm{mL} /$ year, and the stained cells percentage for Ki-67 (Table 2).

In the multivariate study, the influential variables were PSA-DT $<6$ months, PSA velocity in $\mathrm{ng} / \mathrm{mL} /$ year, PSA velocity with the best cut-off point as $0.84 \mathrm{ng} / \mathrm{mL} /$ year, and seminal vesicle involvement (Table 2).

PT3b patients had a RFS of $65 \pm 6 \%$ and $45 \pm 7 \%$ at 5 and 10 years, respectively. The median time to CR was 8 years (95\% Cl 5-11 years). In patients without seminal vesicle involvement, the RFS was $82 \pm 3 \%$ and $72 \pm 4 \%$ at 5 and 10 years, respectively $(p<0.000)$.

RFS at 5 and 10 years was $53 \pm 10$ and $47 \pm 11$, respectively, for the PSA-DT $<6$ months group $(26.8 \%)$ and $89 \pm 4$ and $73 \pm 6$, respectively for the PSA-DT $>6$ months group $(73.2 \%)(p=0.002)$.

Patients with a PSA velocity $>0.84 \mathrm{ng} / \mathrm{mL} /$ year had a RFS at 5 and 10 years of $52 \pm 10 \%$ and $45 \pm 10 \%$, respectively, versus $92 \pm 3 \%$ and $75 \pm 7 \%$ in patients with a PSA velocity $<0.84 \mathrm{ng} / \mathrm{mL} /$ year $(p=0.001)$.

Specific survival (SS) in patients with BCR treated with ADT at 5, 10 and 15 years after surgery was $96 \pm 1 \%$, $85 \pm 2 \%$, and $76 \pm 4 \%$, respectively (patients at risk $=147$, 85 and 31). SS at a median follow-up of 9.2 years was not available. In 17.4 years, the SS was $61 \pm 8$, with 9 remaining patients at risk (Fig. 2).

In the multivariate study, only PSA velocity $>0.84 \mathrm{ng} / \mathrm{mL} /$ year was influential (HR 19.9; 95\% Cl 12.4-162.2, $p=0.05)$.

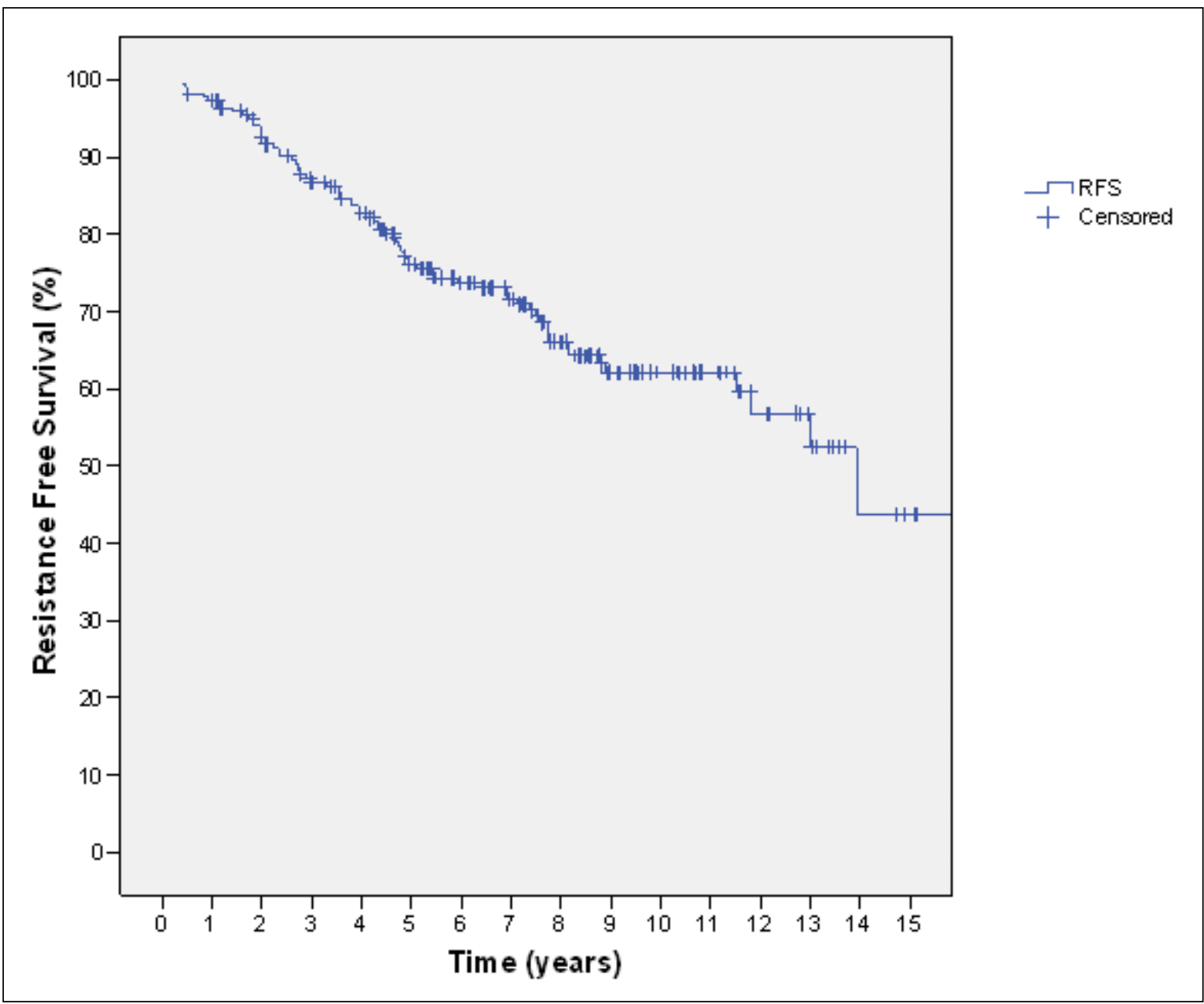

\begin{tabular}{cccccc}
\hline & Failure (\%) & RFS to $\mathbf{5}$ years $(\%)$ & RFS to $\mathbf{1 0}$ years (\%) & Patients at risk to $\mathbf{5}$ years & Patients at risk to $\mathbf{1 0}$ years \\
\hline RFS & 48.4 & $76 \pm 3$ & $62 \pm 3$ & 93 & 39
\end{tabular}

Fig. 1. Castration resistance free survival (RFS) in patients with biochemical recurrence on treatment with androgen deprivation ( $N=159)$. *With a median follow-up of 9.2 years, the RFS median in patients treated with androgen deprivation by biochemical recurrence is 14 years, $95 \%$ confidence interval (11-17). 
Table 2. Univariate and multivariate analysis of RFS influencing factors*

\begin{tabular}{|c|c|c|c|c|c|c|}
\hline & \multicolumn{3}{|c|}{ Univariate } & \multicolumn{3}{|c|}{ Multivariate } \\
\hline & HR & HR 95\% Cl & $p$ value $^{\dagger}$ & HR & HR $95 \%$ Cl & $p$ value $^{\dagger}$ \\
\hline Initial PSA (ng/mL) & 1.004 & $0.9-1.02$ & $\leq 0.5$ & & & NS \\
\hline $\mathrm{PSA}>20 \mathrm{ng} / \mathrm{mL}$ & 1.1 & $0.7-1.9$ & $\leq 0.5$ & & & NS \\
\hline BMI $\left(\mathrm{kg} / \mathrm{m}^{2}\right)$ & 1.04 & $0.9-1.1$ & $\leq 0.4$ & & & NS \\
\hline T2 vs. T1 & 1.4 & $0.8-2.5$ & $\leq 0.1$ & & & NS \\
\hline Unilateral vs bilateral biopsy & 2 & $0.9-4.5$ & $\leq 0.09$ & & & NS \\
\hline Gleason score 8-10 & 1.4 & $0.8-2.4$ & $\leq 0.2$ & & & NS \\
\hline High-risk D’Amico & 1.5 & $0.8-2.5$ & $\leq 0.1$ & & & NS \\
\hline First 500 surgeries $2000-2009$ vs. $1989-1999$ & 1.9 & $1.01-3.4$ & $\leq 0.04$ & & & NS \\
\hline Ki-67 & 1.02 & $1.005-1.04$ & $\leq 0.01$ & & & NS \\
\hline Ki-67 >10\% & 2.4 & $1.1-5.2$ & $\leq 0.02$ & & & NS \\
\hline PSA-DT $<6$ months & 3 & $1.4-6.8$ & $\leq 0.007$ & 3.2 & $1.4-7.2$ & $\leq 0.004$ \\
\hline PSA velocity (ng/mL/year) & 1.3 & $1.1-1.6$ & $\leq 0.002$ & 1.3 & $1.1-1.5$ & $\leq 0.002$ \\
\hline PSA velocity $>0.84 \mathrm{ng} / \mathrm{mL} /$ year & 4 & $1.7-9.4$ & $\leq 0.001$ & 4 & $1.7-9.4$ & $\leq 0.001$ \\
\hline Surgical margins & 1.2 & $0.7-1.9$ & $\leq 0.5$ & & & NS \\
\hline Pathological Gleason 8-10 & 1.8 & $1.1-2.9$ & $\leq 0.02$ & & & NS \\
\hline Seminal vesicle involvement & 2.8 & $1.7-4.6$ & 0.000 & 3.1 & $1.5-6.2$ & $\leq 0.001$ \\
\hline
\end{tabular}

Patients with a PSA velocity $>0.84 \mathrm{ng} / \mathrm{mL} /$ year had a SS at 5 and 10 years of $96 \pm 3 \%$ and $68 \pm 10 \%$, respectively, since surgery (28 and 10 at-risk patients, respectively).

In the 77 patients with CR, the SS median time from surgery to death was 10.2 years (range: 6.9-13.5).

\section{Time since $C R$ to death}

From the 77 patients, $24(31.2 \%)$ are currently living in state of BCR and CR, $6(7.8 \%)$ have died due to other causes and $47(61 \%)$ have died as a result of their prostate cancer. The SS time from CR was $30 \pm 6 \%$ in 5 years. The SS median time was 3.2 years $(95 \% \mathrm{Cl}$, range: $2.6-3.9)$ (Fig. 3).

Table 3. Univariate and multivariate analysis of SS influencing factors in CR patients*

\begin{tabular}{|c|c|c|c|c|c|c|}
\hline & \multicolumn{3}{|c|}{ Univariate } & \multicolumn{3}{|c|}{ Multivariate } \\
\hline & HR & HR $95 \%$ Cl & $p$ value $^{\dagger}$ & HR & HR 95\% Cl & $p$ value $^{\dagger}$ \\
\hline Initial PSA (ng/mL) & & & NS & & & NS \\
\hline $\mathrm{PSA}>20 \mathrm{ng} / \mathrm{mL}$ & & & NS & & & NS \\
\hline BMI $\left(\mathrm{kg} / \mathrm{m}^{2}\right)$ & & & NS & & & NS \\
\hline T2 vs T1 & & & NS & & & NS \\
\hline Unilateral vs. bilateral biopsy & & & NS & & & NS \\
\hline Gleason score 8-10 & & & NS & & & NS \\
\hline High-risk D’Amico & & & NS & & & NS \\
\hline First 500 surgeries $2000-2009$ vs. $1989-1999$ & & & NS & & & NS \\
\hline PSA-DT $<6$ months & & & NS & & & NS \\
\hline PSA velocity (ng/mL/year) & & & NS & & & NS \\
\hline PSA velocity $>0.84 \mathrm{ng} / \mathrm{mL} /$ year & & & NS & & & NS \\
\hline Surgical margins & & & NS & & & NS \\
\hline Seminal vesicle involvement & & & NS & & & NS \\
\hline Pathological Gleason 8-10 & 1.9 & $1.04-3.8$ & $\leq 0.03$ & & & NS \\
\hline Ki-67 & 1.05 & $1.008-1.09$ & $\leq 0.02$ & 1.05 & $1.008-1.09$ & $\leq 0.02$ \\
\hline
\end{tabular}




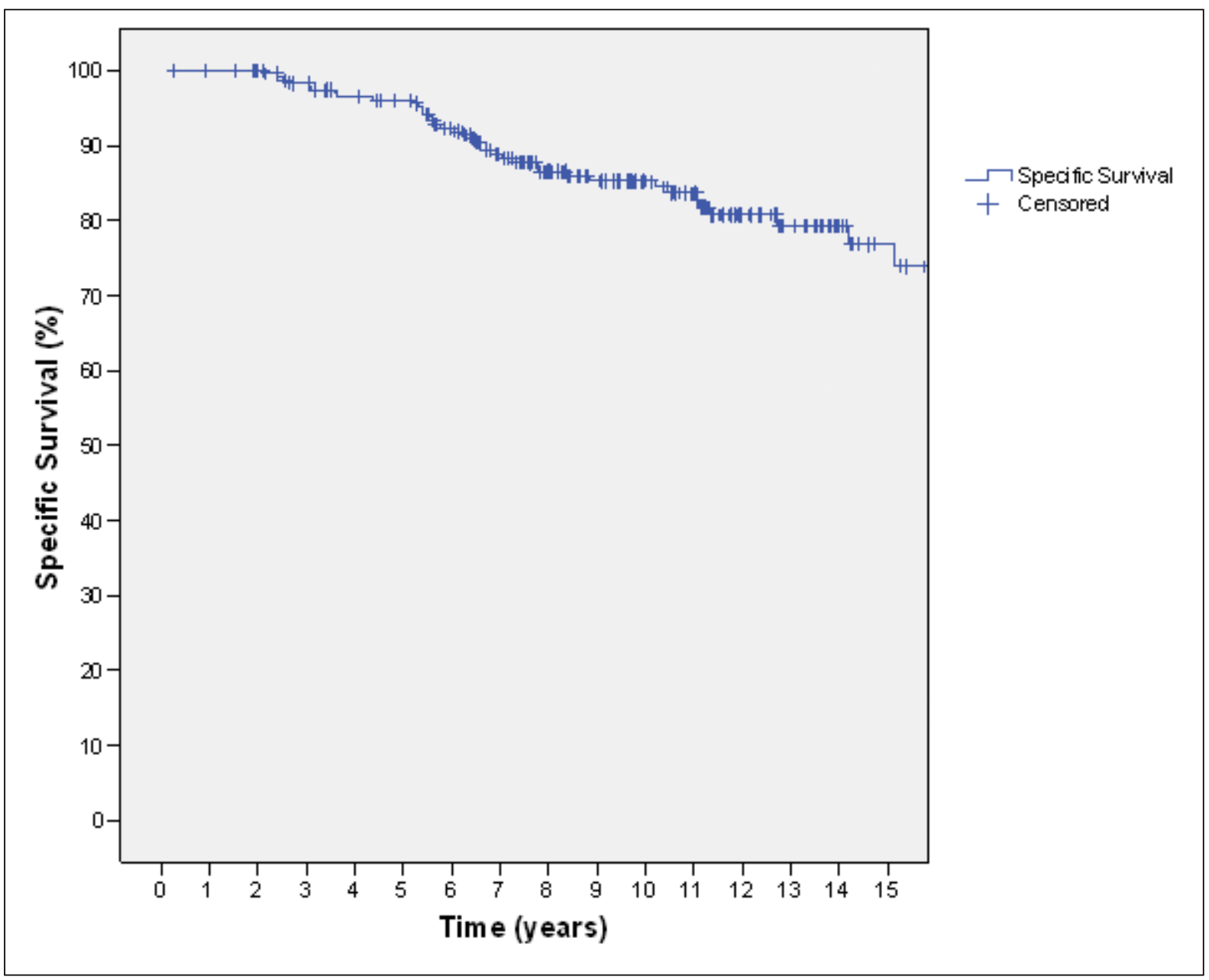

\begin{tabular}{cccccc}
\hline & Failure (\%) & SS to $\mathbf{5}$ years (\%) & SS to $\mathbf{1 0}$ years $(\%)$ & Patients at risk to $\mathbf{5}$ years & Patients at risk to $\mathbf{1 0}$ years \\
\hline SS & 29.5 & $96 \pm 1$ & $85 \pm 2$ & 147 & 85 \\
\hline
\end{tabular}

Fig. 2. Specific survival (SS) in patients with biochemical recurrence on treatment with androgen deprivation ( $N=159)$. SS median is not available. *With a median follow-up of 9.2 years from surgery to death, we do not have SS median.

In the univariate analysis, the Ki-67 marker and the pathological Gleason score 8-10 were SS influential variables. Nonetheless, in the multivariate analysis only Ki-67 had independent influence (Table 3).

The median time to death of patients with $\mathrm{Ki}-67>10 \%$ stained cells was 11 months $(95 \% \mathrm{Cl}$, range: $8-15)$ versus 5.5 years in those with $\mathrm{Ki}-67<10 \%$ stained cells. The median time to death of patients with Gleason score 8-10 was 2.7 years $(95 \% \mathrm{Cl}$, range: $2.5-4)$.

\section{Discussion}

Patients with localized prostate cancer with BCR after surgery are treated half the time with ADT. ${ }^{20,21}$ This treatment shows a favourable clinical response in $80 \%$ of cases and, although it is always temporary and incomplete, it probably extends to the overall survival of patients. Its therapeutic benefit in the short term is unquestionable.

All patients treated with ADT become hormone-refractory ${ }^{22}$ when they start to show a biochemical and clinical recurrence which leads to death. In metastatic patients with this treatment, $35 \%$ to $40 \%$ fail in the first year, $50 \%$ die before 3 years and only 5\% to $10 \%$ live beyond 10 years. However, $66 \%$ of the metastatic patients who have not received ADT die within 9 months. ${ }^{23}$

In patients with localized prostate cancer with BCR, CR occurs much later in life. In our study, with a remarkable median follow-up of 9.2 years, the median time since surgery to CR was 14 years (from BCR 11.5 years, data not shown). There are several studies on BCR in patients treated with immediate or deferred ADT. The first extensive study was published by a Johns Hopkins group ${ }^{1}$ and analyzed 


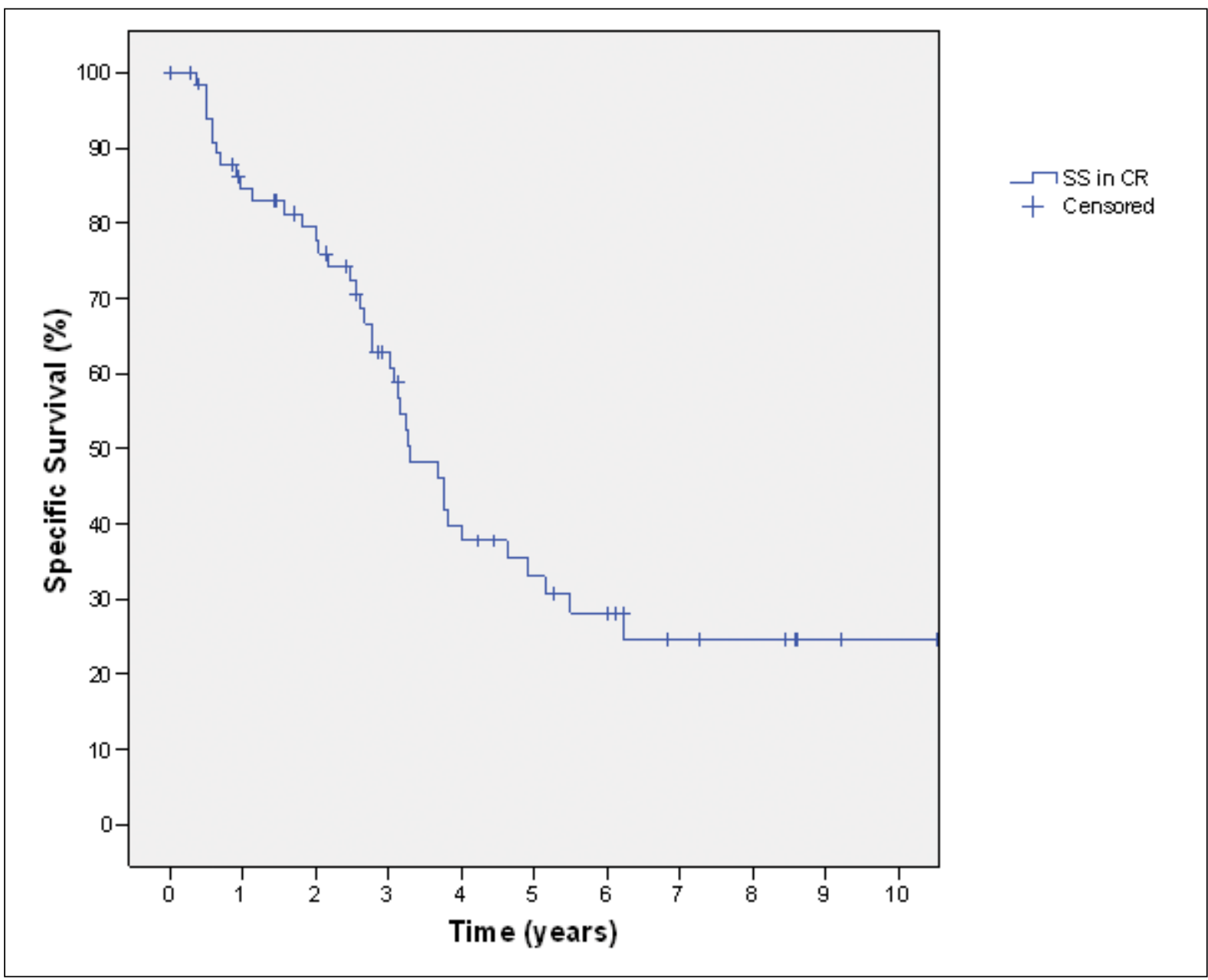

\begin{tabular}{lccc}
\hline & Failure (\%) & SS in CR to 5 years (\%) & Patients at risk to 5 years \\
\hline SS in CR & 61 & $30 \pm 6$ & 14 \\
\hline
\end{tabular}

Fig. 3. Specific survival (SS) in castration resistant (CR) patients ( $N=77)$. SS median of 3.2 years, $95 \%$ confidence interval (2.6-3.9).

304 patients (of the 1997 patients undergoing radical surgery) who were treated with ADT until death, who had a PSA $>0.2 \mathrm{ng} / \mathrm{mL}$ and who were not treated until evidence of metastasis disease. The median time to metastatic disease was 8 years (in 5 years, 63\% were free of metastasis disease) and it depended on the time from surgery to BCR $(<2$ years), on the PSA-DT $<10$ months and on the pathological Gleason 8-10. Since the development of metastatic disease, the median survival was less than 5 years. The only influential variable was the time from surgery to the development of metastatic disease (1-3 years vs. rest). In our study, the treatment started the moment in which BCR occurred, so we were only able to compare the SS, which is better in our case (17 years from surgery, 15 years from BCR) despite having a higher tracking.

We compared our data with those published in another extensive study. ${ }^{10}$ This study analyzed 379 patients and showed a SS of $55 \%$ at 15 years (with a median follow-up of 10 years, SS median was not available). In our study, the SS at 15 years was $76 \%$ and we did not have either a SS median with the current tracking. The only difference in treatment was the time when it started (which was immediately in our study, and when the metastatic disease appeared in the other study. ${ }^{10}$ )

Another extensive study included 213 patients with BCR, with no variation in survival in 10 years from those who do not have recurrence ( $88 \%$ vs. $93 \%$, respectively) and $74 \%$ in those who have not metastatic disease. ${ }^{2}$ However, in our study there were significant differences between those who had BCR and those who did not. This difference was because the tracking was much higher in our study than in the other study (56 months from surgery, 34 from BCR). Rogers and colleagues studied patients with clinically localized cancer undergoing radical prostatectomy and whose PSA was never 
negative, with 160 non-treated patients until there was evidence of metastatic disease. ${ }^{24}$ At the end of the study, $21 \%$ of patients died as a result of prostate cancer and $47 \%$ had metastatic disease. The metastasis-free survival probability at 3, 5, 7 and 10 years was $68 \%, 49 \%, 38 \%$, and $22 \%$, respectively. The factors of influence were Gleason 8-10, median time to metastasis disease 2.5 years versus 6 years and above all the PSA rise curve inclination.

Some authors have found that a Gleason score 8-10 significantly influenced SS; this demonstrates that SS can be a prognostic factor in patients with CRPC..$^{25-30}$

$\mathrm{CR}$ is the last step of an evolutionary scale whose point of departure is BCR. This resistance is determined by a series of intrinsic clinic-pathological tumour characteristics. The aim of the present study was to show the influential variables from surgery to CR and from CR to death. In addition to the conventional clinical-pathological variables, we emphasized that the PSA-DT prognostic value, a measurement that determines the biological activity of tumour, has capital prognostic value. ${ }^{31}$ Typically, a PSA-DT of more than 80 days is associated with better treatment results. ${ }^{32}$ In fact, in 2 large trials (i.e., the South West Oncology Group [SWOG 9916] ${ }^{33}$ or the Cancer and Leukemia Group B $\left.[\mathrm{CALGB}]^{34}\right)$, the PSADT was the decisive criterion in the survival of patients. In our study, the CR independent predictive factors were seminal vesicle involvement, PSA-DT $<6$ months and PSA velocity $>0.84 \mathrm{ng} / \mathrm{mL} /$ year.

From CR to death, although a Gleason score 8-10 was a factor of influence in the univariate study, contrary to other published papers, it was not influential in the multivariate study. Perhaps this was the case because of the evolution in the type of patient candidate to radical prostatectomy in 20 years, ${ }^{35}$ or because of the changes in the pathological qualification criteria with a tendency to upgrade the Gleason score, ${ }^{36}$ or because of the clinic-pathological stage migration of this disease. ${ }^{37,38}$

The only death survival independent predictor factor was the $\mathrm{Ki}-67$ value. $\mathrm{Ki}-67$ is a nuclear antigen in the G1, S, G2 and M phases of the cell cycle. It correlates with cell proliferation and it indirectly indicates an intense biological tumour activity and poor prognosis. ${ }^{18,39-41}$ For every $1 \%$ of stained tissue that increases the expression of this marker, the risk of death in prostate cancer increases by $5 \%$ (HR:1.05; $95 \% \mathrm{Cl} 1.008-1.09, \mathrm{p}<0.02)$. The best cut-off point is $10 \%$ of stained cells (median survival from CR to death is 11 months if it is higher than $10 \%$ and 5.5 years if it is less than $10 \%)$. The originality of these data is obvious because they have not been published yet. It has a notable importance because if confirmed, these findings will lead us to a new prognosis assessment in these types of tumours. It also has the great advantage in that it is technically easy to analyze by immunohistochemistry with any prostate tissue (transure- thral resection material, ${ }^{40}$ prostate biopsy material, ${ }^{41}$ radical prostatectomy specimen ${ }^{18}$ ) and it can easily be done at any histopathology department.

Finally, despite $75.3 \%$ (58 of 77 ) of patients with CR currently with metastatic disease, we have not studied the influence of time until metastatic disease in SS. We have not considered either the time from radical prostatectomy to BCR in association with SS. This is a major limitation of our study as long as there are published studies which show that this association with SS is an independent factor of influence. ${ }^{10}$ In addition, it is a retrospective study, from a single centre and not centralized, in which the small number of patients does not allow us to make stronger assertions.

\section{Conclusion}

With a median follow-up of 9.2 years in BCR patients treated with AD, the RFS median was 14 years (SS median time from surgery was not available). The RFS was $76 \pm 3 \%, 62 \pm 3 \%$ and $43 \pm 9 \%$ at 5,10 and 15 years, respectively. The PSA-DT $<6$ months, seminal vesicles involvement and PSA velocity $>0.84 \mathrm{ng} / \mathrm{mL} /$ year were influential variables for RFS.

In the 77 patients with CR, the SS median time from surgery to death was 10.2 years. The median time from CR to death was 3.2 years. The only independent prognostic factor was $\mathrm{Ki}-67$.

Competing interests: Dr. Algarra, Dr. Hevia, Dr. Tienza, Dr. Merino, Dr. Velis, Dr. Zudaire, Dr. Robles, and Dr. Pascual all declare no competing financial or personal interests.

This paper has been peer-reviewed.

\section{References}

1. Pound CR, Partin AW, Eisenberger MA, et al. Natural history of progression after PSA elevation following radical prostatectomy. JAMA 1999;281:1591-7. http://dx.doi.org/10.1001/jama.281.17.1591

2. Jhaveri FM, Zippe $C D$, Klein $E A$, et al. Biochemical failure does not predict overall survival after radical prostatectomy for localized prostate cancer: 10-year results. Urology 1999;54:884-90. http://dx.doi. org/10.1016/S0090-4295(99)00252-6

3. Frazier $\mathrm{HA}$, Robertson JE, Humphrey PA, et al. Is prostate specific antigen of clinical importance in evaluating outcome after radical prostatectomy? J Urol 1993; 149:516-8.

4. Morgan WR, Bergstralh EJ, Zincke H. Long-term evaluation of radical prostatectomy as treatment for clinical stage C (Т3) prostate cancer. Urology 1993;41:113-20. http://dx.doi.org/10.1016/00904295(93)90159-8

5. Paulson DF. Impact of radical prostatectomy in the management of clinically localized disease. I Urol 1994; 152:1826-30.

6. Stein A, deKernion JB, Dorey F. Prostatic specific antigen related to clinical status 1 to 14 after radical prostatectomy. Br J Urol 1991;67:626-31. http://dx.doi.org/10.1111/j.1464-410X.1991.tb15228.x

7. De Witt R. Chemotherapy in hormone-refractory prostate cancer. BJU Int 2008;101 (Suppl 2):11-5. http://dx.doi.org/10.1111/j.1464-410X.2007.07485.x

8. Vogelzang NJ, Crawford ED, Zietman A. Current clinical trial design issues in hormone-refractory prostate carcinoma. Cancer 1998;82:2093-101. http://dx.doi.org/10.1002/(SICI) 10970142(19980601)82:11<2093::AID-CNCR3>3.0.C0;2-X 
9. Scher HI, Mazumdar M, KellyWK. Clinical trials in relapsed prostate cancer: Defining the target. J Natl Cancer Inst 1996;88:1623-34. http://dx.doi.org/10.1093/inci/88.22.1623

10. Freedland SJ, Humphreys EB, Mangold LA, et al. Risk of prostate cancer-specific mortality following biochemical recurrence after radical prostatectomy. JAMA 2005;294:433-9. http://dx.doi.org/10.1001/ jama.294.4.433

11. Yossepowitch 0, Bianco FJ Jr, Eggener SE, et al. The natural history of noncastrate metastatic prostate cancer after radical prostatectomy. Eur Urol 2007;51:940-7; discussion 947-8. Epub 2006 Oct 30. http://dx.doi.org/10.1016/i.eururo.2006.10.045

12. Ward JF, Blute ML, Slezak J, et al. The long-term clinical impact of biochemical recurrence of prostate cancer 5 or more years after radical prostatectomy. J Urol 2003;170:1872-6. http://dx.doi.org/10.1097/01. ju.0000091876.13656.2e

13. D'Amico AV, Moul JW, Carroll PR, et al. Surrogate end point for prostate cancer-specific mortality after radical prostatectomy or radiation therapy. J Natl Cancer Inst 2003;95:1376-83. http://dx.doi. org/10.1093/inci/dig043

14. Zhou P, Chen MH, McLeod D, et al. Predictors of prostate cancer-specific mortality after radical prostatectomy or radiation therapy. J Clin Oncol 2005;23:6992-8. http://dx.doi.org/10.1200/JC0.2005.01.2906

15. Saad F, Hotte S, Catton C, et al. CUA-CUOG guidelines for the management of castration-resistant prostate cancer (CRPC): 2013 update. Can Urol Assoc J 2013:7:213-7. http://dx.doi.org/10.5489/cuaj.1542

16. Walsh PC. Radical prostatectomy for the treatment of localized prostatic carcinoma. Urol Clin North Am 1980;7:583-91.

17. True LD. Surgical pathology examination for the prostate gland: practice survey by the American Society of Clinical Pathologist. Am I Clin Pathol 1994; 102:572-9.

18. Zudaire JJ, Sánchez D, Arocena J, et al. p53 and Kib7 expression in specimens of radical prostatectomy. Relationship with clinico-pathologic data and survival. Actas Urol Esp 2000;24:307-13.

19. Amling $\mathrm{CL}$, Bergstralh EJ, Blute ML, et al. Defining prostate specific antigen progression after radical prostatectomy: what is the most appropriate cut point? J Urol 2001;165:1146-51. http://dx.doi. org/10.1016/50022-5347(05) 66452-X

20. Parker C, Warde $P$, Catton C. Salvage radiotherapy for PSA failure after radical prostatectomy. Radiother Oncol 2001;61:107-16. http://dx.doi.org/10.1016/S0167-8140(01)00439-X

21. Ornstein DK, Colberg JW, Virgo KS, et al. Evaluation and management of men whose radical prostatectomies failed: Results of an international survey. Urology 1998;52:1047-54. http://dx.doi.org/10.1016/ S0090-4295(98)00403-8

22. Crawford ED, Eisenberger MA, McLeod DG, et al. A controlled trial of leuprolide with and without flutamide in prostatic carcinoma. N Engl J Med 1989;321:419-24. http://dx.doi.org/10.1056/ NEJM198908173210702

23. Aus $G$. Prostate cancer. Mortality and morbidity after non-curative treatment with aspects on diagnosis and treatment. Scand I Urol Nephrol Suppl 1994;167:1-41.

24. Rogers $(G$, Khan MA, Craig Miller M, et al. Natural history of disease progression in patients who fail to achieve an undetectable prostate-specific antigen level after undergoing radical prostatectomy. Cancer 2004;101:2549-56. http://dx.doi.org/10.1002/cncr.20637

25. Halabi S, Small EJ, Kantoff PW, et al. Prognostic model predicting survival in men with hormonerefractory metastatic prostate cancer. J Clin Oncol 2003;21:1232-7. http://dx.doi.org/10.1200/ $\mathrm{JC} 0.2003 .06 .100$

26. Smaletz 0 , Scher HI, Small EJ, et al. A nomogram for overall survival of patients with progressive metastatic prostate cancer following castration. J Clin Oncol 2002;20:3972-82. http://dx.doi.org/10.1200/ JC0.2002.11.021
27. Berry WR, Laszlo J, Cox E, et al. Prognostic factors in metastatic and hormonally unresponsive carcinoma of the prostate. Cancer 1979;44:763-75. http://dx.doi.org/10.1002/1097-0142(197908)44:2<763::AlDCNCR2820440251>3.0.C0;2-5

28. Emrich U, Priore RL, Murphy GP, et al. Prognostic factors in patients with advanced stage prostate cancer. Cancer Res 1985;45:5173-9.

29. Pienta KJ, Redman B, Hussain $M$, et al. Phase II evaluation of oral estramustine and oral etoposide in hormone-refractory adenocarcinoma of the prostate. J Clin Oncol 1994;12:2005-12.

30. Petrylak DP, Scher HI, Li Z, et al. Prognostic factors for survival of patients with bidimensionally measurable metastatic hormone-refractory prostatic cancer treated with single-agent chemotherapy. Cancer 1992;70:2870-8. http://dx.doi.org/10.1002/1097-0142(19921215)70:12<2870::AlDCNCR2820701225>3.0.C0;2-F

31. Patel A, Dorey F, Franklin J, et al. Recurrence patterns after radical retropubic prostatectomy: Clinical usefulness of prostate specific antigen doubling times and log slope prostate specific antigen. J Urol 1997;158:1441-5. http://dx.doi.org/10.1016/S0022-5347(01)64238-1

32. Akimoto S, Masai M, Akakura K, et al. Tumor marker doubling time in patients with prostate cancer: Determination of prostate-specific antigen and prostatic acid phosphatase doubling time. Eur Urol 1995;27:207-12.

33. Hussain $M$, Goldman B, Tangen C, et al. Prostate-specific antigen progression predicts overall survival in patients with metastatic prostate cancer: Data from Southwest Oncology Group Trials 9346 (Intergroup Study 0162) and 9916. J Clin Oncol 2009;27:2450-6. http://dx.doi.org/10.1200/ JC0.2008.19.9810

34. Halabi S, Vogelzang NJ, Ou SS, et al. Progression-free survival as a predictor of overall survival in men with castrate-resistant prostate cancer. J Clin Oncol 2009;27:2766-71. http://dx.doi.org/10.1200/ JC0.2008.18.9159

35. Algarra R, Zudaire J, Rosell $D$, et al. Course of the type of patient who is candidate for radical prostatectomy over 2 decades (1989-2009). Actas Urol Esp 2013;37:347-353. http://dx.doi.org/10.1016/i. acuro.2012.09.005

36. Smith EB, Frierson HF Jr, Mills SE, et al. Gleason scores of prostate biopsy and radical prostatectomy specimens over the 10 years: Is there evidence for sustematic upgrading? Cancer 2002;94:2282-7. http://dx.doi.org/10.1002/cncr.10457

37. Cooperberg MR, Moul JW, Carroll PR. The changing face of prostate cancer. J Clin Oncol 2005;23:814651. http://dx.doi.org/10.1200/JC0.2005.02.9751

38. Cooperberg MR, Lubeck DP, Mehta SS, et al. Time trends in clinical risk stratification for prostate cancer: Implications for outcomes (data from CaPSURE). J Urol 2003;170:S21-5; discussion S26-7.

39. Feneley MR, Young MP, Chinyama C, et al. Ki-67 expression in early prostate cancer and associated pathological lesions. J Clin Pathol 1996;49:741-8. http://dx.doi.org/10.1136/icp.49.9.741

40. Nilsson $S$, Nordgren $H$, Karlberg $L$, et al. Expresion of estramustinebinding protein (EMBP) and the proliferation associated antigen Ki-67 in prostatic carcinomas. Scand J Urol Nephrol Supp/ 1998;110:31-7.

41. Ojea CA, Mosteiro Cervino MJ, Dominguez FF, et al. The usefulness of Ki67 expression in the biopsy specimens to predict the biochemical progression of the prostate cancer after radical prostatectomy. Actas Urol Esp 2004;28:650-60.

Correspondence: Dr. Rubén Algarra, University of Navarra Clinic, Navarra, Spain, Avda. Pío XII, 36. 31008 Pamplona. Spain; fax: +34 948296 500; ralgarra@unav.es 